AL-IQTISHOD: Jurnal Pemikiran dan Penelitian Ekonomi Islam E-ISSN: 2407-6600 P-ISSN: 2745-85I2

Volume IO Issue I Januari 2022 | Page: 063-078 DOI: https://doi.org/I0.37812/aliquishod

\title{
Pemikiran Ekonomi Ibnu Taimiyah
}

\author{
Riska Awalia \\ UIN SUNAN AMPEL, Surabaya, Indonesia \\ 05010220021@student.uinsby.ac.id
}

\begin{abstract}
This study discusses the main ideas in cartying out economic activities cartied out by the community in accordance with Islamic teachings developed by the thought of Ibn Taimiyah who is famous for the al-ruju' ila Al-Qur'an movement (back to the source of Islamic teachings, namely the Al-Qur'an). 'an 'an and As-sunnah), which Ibn Taimiyah's thoughts provide solutions to the state in building development morality by making people aware that morals and ethics are important in carrying out economic activities. The purpose of this research is to provide an overview of the main things that must be present when you want to carry out economic activities in accordance with Islamic views. As for this study, we used a descriptive literature research method that included the main ideas about Islamic economics in terms of Ibn Taimiyah's thoughts and the principles of economic activity according to Islamic teachings. Because when someone wants to carry out economic activities, the main thing that must be done is to include Islamic economic principles in these activities because economic activities are not directly related to someone. In carrying out economic activities, one must be able to understand and also apply the principles or rules that have been established in Islamic teachings. So things that are not desirable, such as the existence of a monopoly, are the goals of Islamic economic thought according to Ibn Taimiyah.
\end{abstract}

keywords: history; Islamic economics;Ibn Taimiyah

Abstrak: Penelitian ini membahas tentang gagasan-gagasan pokok dalam melakukan kegiatan ekonomi yang dilakukan masyarakat sebagaimana ajaran Islam menentukan yang dikembangkan oleh pemikiran Ibn Taimiyah yang terkenal dengan gerakan al-ruju' ila Al-Qur'an (kembali pada sumber ajaran islam, yaitu Al-Qur'an dan As-sunnah), yang mana pemikiran Ibn Taimiyah ini memberikan solusi kepada negara dalam membangun morarilitass pembangunan dengan upaya menyadarkan rakyat bahwa moral dan etika merupakan hal yang penting dalam melakukan kegiatan perekonomian. Tujuan diadakannya penelitian ini yaitu untuk memberikan gambaran mengenai hal-hal pokok yang harus ada pada saat ingin melakukan kegiatan ekonomi yang sesuai dengan pandangan islam. Adapun dalam Penelitian ini kami menggunakan metode penelitian deskriptif kepustakaan yang mencakup gagasan-gagasan utama mengenai ekonomi islam yang di tinjau dari pemikiran Ibn Taimiyah serta prinsip-prinsip mengenai kegiatan ekonomi menurut ajaran islam. Sebab ketika seseorang ingin melakukan kegiatan perekonomian hal utama yang harus dilakukan adalah mengikut sertakan prinsip-prinsip ekonomi islam dalam kegiatan tersebut karena secara tidak langsung kegiatan ekonomi juga ada keterkaitannya dengan keimanan seseorang. Dalam melakukan kegiatan ekonomi haruslah bisa memahami dan juga menerapkan prinsip-prinsip atau aturan aturan yang telah di tetapkan didalam ajaran Islam. Sehingga hal-hal yang tidak di inginkan seperti adanya monopoli seprti tujuan dari pemikiran ekonomi islam menurut Ibnu Taimiyah.

Kata Kunci: sejarah, ekonomi islam, Ibn Taimiyah 



\section{A. Pendahuluan}

Tanpa kita sadari di dalam kehidupan ini seorang manusia tidak akan pernah lepas dari yang namanya muamalah (kegiatan yang bersangkutan dengan kebutuhan), agar dapat memenuhi kebutuhan kehidupannya manusia. Pastinya akan melakukan transaksi perekonomian. Menjalankan suatu kegiatan perekonomian yang benar dan selaras dengan pandangan islam, tentunya orang tersebut membutuhkan adanya hukum atau dalil yang jelas. Sebab dalam bermuamalah hukumnya semuanya boleh, kecuali ada dalil yang melarangnya. Sehingga seseorang perlu untuk mendengarkan Fatwa ataupun membaca Al-Quran ataupun hadis yang menerangkan tentang muamalah.

Ibn taimiyah merupakan salah satu tokoh ekonomi islam yang juga mashur dikalangan masyarakat, karena pemikirnnya terhadap perekonomian berbasis islam sebab dalam pemikirannya segala hal yang bersangkutan dengan perekonomian haruslah berlandasan terhadap Al-Qur'an ataupun As-sunnah. Dan beliau juga merupakan salah satu tokoh da'i, pembaharu dan tokoh ekonomi islam yang sangat monumental sebab pemikirannya terhadap ekonomi islam di dalam sejarahnya, wawasan yang luas serta tidak pernah mengenal kata menyerah itulah yang membuat masyarakat selalu mengingatnya. Lahirnya Gagasan-gagasan dan upaya yang dilakukan Ibnu Taimiyah berasal dari asumsi dasarnya yang percaya bahwa generasi muslim yang mengalami kemajuan ekonomi akibat berpedoman pada ajaran Islam, sedangkan pada masa Ibnu Taimiyyah kaum muslim di anggap lemah dan kurang di hargai oleh umat lain karena mereka banyak meninggalkan sumber ajarannya. Adapun tujuan utama dari pemikiran Ibn Taimiyah yaitu untuk menghindari adanya praktik monopoli yang dilakakukan oleh pihak-pihak yang tidak bertanggung jawab yang mengakibatkan kerugian terhadap pihak lain.

Di zaman sekarang ini masyarakat muslim sangat membutuhkan hukum dasar perekonomian yang benar untuk melakukan suatu kegiatan usaha, sehingga kajian mengenai ekonomi islam sangat dibutuhkan. Amal perbuatan serta ilmu yang telah di terapkan oleh Ibnu Taimiyah dapat menjadi acuan bagi setiap umat. Sehingga untuk bisa mewujudkan 


\section{Pemikiran Ekonomi Ibn Taymiyah}

adanya suatu kebebasan khususnya dalam hal kepemilikan yang menekankan moral, etika, serta pengawasan yang ketat dan berusaha untuk menegakkan syariat. ${ }^{1}$

Didalam ajaran syariah prilaku individu maupun sekelompok orang di arahkan untuk dapat memenuhi kebutuhannya sekaligus mengelola sumber daya yang tersedia dengan baik dan bijaksana. Subjek yang di pelajari dalam ekonomi islam berbeda dengan penjelasan ekonomi yang dikemukakan oleh Adam Smith, sehingga menimbulkan perbedaan antara ekonomi islam dengan ekonomi umum yang terdapat di kalangan masyarakat. Dalam artikel ini penulis menggunakan metode deskriptif kepustakaan untuk mengungkap sejarah ekonomi islam serta sejarah hidup Ibn Taimiyah yang memberikan dampak terhadap ekonomi islam yang bertujuan untuk menjelaskan tentang ekonomi islam serta prinsip dan gagasan mengenai ekonomi islam menurut pandangan dari Ibn Taimiyah.

\section{B. Kajian Pustaka}

Islam adalah agama yang rahmatan lil alamin yang menjadikan alquran dan al hadist sebagai pedomannya untuk menutun kepada kebahagiaan yang sejati, Dari sini dapat kita ketahui aspek yang ada didunia mulai dari sosial, spritual, hingga berbau perekinomian semuanya sudah tercakup dalam alquran.

Dalam sejarah, ekonomi yang berbasis Islam dimulai sejak masa kepemimpinan Rasulullah SAW yang berlandasan pada Al-qur'an dan juga Hadist. Pada masa itu kegiatan perekonomian diiringi demgan nilai-nilai yang terdapat pada Al-Quran yang berasaskan pada persaudaraan, kebebasan, keadilan, dan persamaan. ${ }^{2}$ Pada masa itu dikalangan masyarakat arab mulai banyak yang melakukan transaksi menggunakan mata uang negara, sehingga istilah barter sudah tidak dipergunakan lagi. Selain itu sistem keuangan yang berlaku menggunakan asas bagi hasil, kerjasama serta keadilan, bahkan pada saat itu praktik riba juga sudah tidak terlihat lagi di masyarakat. Sehubungan dengan ini didalam Al-Quran juga sudah menjelasakan mengenai haramnya melakukan riba, dan jugs memberi solusi untuk menghindari riba yakni dengan cara berzakat, bersedekah. Pada tahun kedua Hijriyah membayar zakat fitrah diwajibkan hingga sekarang

${ }^{1}$ Yasin Jetta, "Pemikiran Hukum Islam Ibnu Taimiyah," Jurnal Ilmiah Al-Syir'ah 8, no. 2 (2010): 1, https://doi.org/10.30984/as.v8i2.19.

2 Lailatul Istiqomah, Pemikiran Ekonomi Islam, and Ekonomi Global, “Jurnal Al-Iqtishod Jurnal Al-Iqtishod" 1, no. 1 (2019): 8. 
Setelah Rasulullah SAW meninggal dunia perekonomian islam semakin berkembang menjadi 3 fase perubahan yaitu :

I. Tahun $\mathrm{I} 82 \mathrm{H}$ atau $789 \mathrm{M}$ pemikiran tentang perekonomian islam mulai muncul misalnya pemikiran dari Abu yusuf dengan kita Alkhorroj yang membahas tentang keuangan publik serta akuntansi yang berbasis syariah. Mawardi dengan kitab Al-ahkham assulthiniyyah, addin waddun'ya membahas tentang prilaku seseorang sebagai konsumen atau produsen. dan lain sebagainya.

2. Tahun 45 I-505 H atau I055-I I I I M pemikiran tentang keamanan ekonomi yang di kemukakan oleh salah satu tokoh yaitu Al-Ghazali dengan kitab ihya' ulumuddin, ushul fiqh, mizan al maal, almusytasyfa dll yang membahas tentang korupsi, riba, penimbunan barang, evolusi uang. Ibn taimiyah dengan kitab al-fatwa dan al-hisab menjelaskan tentang konsep harga yang adil sesuai dengan landasan moral yang terdapat pada masyarakat.

3. Tahun II I4-II76 H atau I703-I762 M pemikiran tentang rasionalisasi pendapatan yang dirumuskan oleh para pakar ekonomi islam seperti Nejatullah siddiqi, shah waliyullah dengan kitabnya yaitu hujjatullah al baligho. ${ }^{3}$

Adapun dalam pemikiran ibn Taimiyah berisi tentang pendeskripsian pemikiran sosial-politik mengenai pemerintahan, kepemimpinan serta hakikat yang ada pada sebuah negara. Gagasan dari Ibn Taimiyah ini dapat mencerminkan adanya perekonomian yang lahir pada abad modern. Menurut pandangan Ibn Taimiyah segala permasalahan yang berkaitan dengan ekonomi hukumnya adalah boleh, kecuali ada dalil yang secara tegas melarang kegiatan tersebut. Dalam syariah semua orang harus bisa mengetahui hal-hal yang terkait dengan ekonomi demi kebaikan bersama sehingga mereka diperbolehkan untuk melakukan transaksi secara bebas, membuat kontrak dan lain sebagainya secara jujur dan terbuka. Sebab jika tidak dilakukan secara terbuka di khawatirkan disuatu hari akan terjadi sebuah korupsi sehingga menyebabkan ketidak adilan dan ketidak merataan ekonomi. Dapat disimpulkan bahwa tujuan utama dari pemikiran Ibn Taimiyah ini adalah untuk menghindari adanya monopoli yang dilakukan oleh pihak-pihak tertentu yang menindas pihak lainnya, sehingga kegiatan ekonomi mikro bagi masyarakat kecil bisa berjalan dengan lancar.

Dalam penetapan harga permintaan dan penawaran di pasar bebas, perlu dipertimbangkan sebagaimana beliau mengatakan "naik turunnya harga tidak selalu berkaitan dengan ke dzoliman yang dilakukan oleh pihak-pihak tertentu, akan tetapi terkadang hal itu

3 fasiha, "Al-Amwal : Journal of Islamic Economic Law September 2017, Vol. 2, No. 2 Http://Www.Iainpalopo.Ac.Id/Index.Php/Amwal," Islamic Economic 2, no. 2 (2017): 114.

Volume. IO/No. I/Januari 2022 Al-Iqtishod | 65 


\section{Pemikiran Ekonomi Ibn Taymiyah}

terjadi karena adanya kekurangan barang-barang yang diminta, sehingga jika membutuhkan peningkatan jumlah barang, sementara kemampuannya menurun maka harga akan naik dengan sendirinya. Di lain sisi apabila kemampuan penyediaan barang meningkat dan permintaannya menurun maka harga akan turun, kelangkaan dan kelimpahan barang tidak mesti diakibatkan oleh perbuatan curang seseorang melainkan dari faktor lain juga. Maha besar Allah, yang menciptakan kemampuan pada hati manusia". 4

Dari pernyataan tersebut dapat kita ambil kesimpulan bahwasannya apabila jumlah kebutuhan terhadap barang meningkat, sedangkan kesediaan barangnya menurun maka harga akan naik dengan sendirinya. Bagitu pula sebaliknya. Dan ini merupakan hukum alam mengenai pasar. Suatu harga barang dapat di pertimbangkan melalui kekuatan penawaran dan juga permintaan secara sendirinya. Akan tetapi beliau juga tidak menyangkal dalam hal kelangkaan barang atau berlimpahnya stok barang yang juga bisa disebabkan dari adanya ketidak adilan yang terjadi. 5

\section{Metode Penelitian}

\section{I.I Proses pengumpulan data:}

a. tinjau literatur

Artikel yang kami tulis ini menggunakan metode pendekatan deskriptif kepustakaan. Dimana didalam metode ini kami ingin mencoba memberikan gambaran kepada masyarakat mengenai penjelasan perihal ekonomi islam, yang disadari atau tidak telah terjadi di lingkungan kita sehingga penelitian ini dilakukan dengan tujuan dapat menjadi salah satu refrensi kajian yang dapat memberikan gambaran mengenai ekonomi berbasis islam yang ditinjau dari perspektif Ibnu Taimiyah.

Adapun dalam artikel ini kami hanya menuliskan inti pokok dari pemikiran ekonomi islam menurut pandangan Ibnu Taimiyah untuk lebih mudah dipahami oleh para pembaca dan bisa menjadi salah satu sumber ladang ilmu pengetahuan tambahan mengenai pemikiran ekonomi islam.

b. Merumsukan dan menyusun pertanyaan permasalahan

I. bagaimana biografi ibn taimiyah

${ }^{4}$ M Khoirur Rofiq, "Pemikiran Ekonomi Islam Ibnu Taimiyah," An-Nawa, Jurnal Hukum Islam 22, no. 1 (2018): 33.

5 Syarial Dedi, "Ekonomi Dan Penguasa (Pemikiran Ibn Taimiyah Tentang Mekanisme Pasar)," AL-FALAH : Journal of Islamic Economics 3, no. 1 (2018): 78, https://doi.org/10.29240/jie.v3i1.442.

66| Al-Iqtishod Volume. IO/No. I/Januari 2022 
2. bagaimana prinsip ekonomi islam menurut ibn taimiyah

3. Bagaimana pemikiran Ibn Taimiyah dalam pokok-pokok ekonomi islam

\section{I.II Teknik Pengumpulan Data}

I. Observasi

Penulis menggunakan teknik pengumpulan data observasi dengan melakukan pengamatan dan pencatatan terhadap objek penelitian yaitu: pandangan Ibn Ttaimiyah terhadap eonomi islam, observasi dilakukan melalui kajian literatur berupa sumber-sumber yang terkait dengan objek penelitian menggunakan jenis literatur jurnal penelitian. Hasil observasi penulis pemikiran dari ibn taimiyah, beliau merupakan seorang ulama yang bernasab dari imam besar yakni imam hambali,beliau juga merupakan tokoh ulama yang mempelajari bidang fiqh, hadis, tafsir Al-Qur'an, matematika, filsafat sehingga dalam pandangan ibn taimiyah menegai ekonomi islam lebih mengarah kepada kesesuaian ekonomi islam yang terdapat dalam Al-Qur'an dan Hadist. Hal itu dikarenakan Ibn Taimiyah menyandarkan pandangannya kepada sumber hukum islam. Pemikiran Ibn Taimiyah terhadap ekonomi islam bertujuan untuk menghindari monopoli, mengindari sikap sewenag-wenang pemerintah terhadap masyarakat kecil

\section{I.I II Jenis Data}

\section{Data Kuantitatif}

Data kuantitatif merupakan data naratif atau deskriptif mengenai suatu objek penelitian. Dalam hal ini yang menjadi objek adalah pemikiran dari Ibn Taimiyah mengenai ekonomi islam.

a. Deskripsi Pemikiran dari ibn taimiyah

Ibn Taimiyah merupakan seorang ulama yang bernasab dari imam besar yakni imam hambali ,beliau merupakan salah satu tokoh ulama yang mempelajari bidang fiqh, hadis, tafsir Al-Qur'an, matematika, filsafat. Sehingga dalam pandangan Ibn Taimiyah menegai ekonomi islam lebih mengarah kepada kesesuaian ekonomi islam yang terdapat dalam Al-Qur'an dan Hadist. Hal itu dikarenakan Ibn Taimiyah menyandarkan pandangannya kepada sumber hukum islam. Pemikiran Ibn Taimiyah terhadap ekonomi islam bertujuan untuk menghindari adanya monopoli, mengindari sikap sewenag-wenang pemerintah terhadap masyarakat kecil.

Volume. IO/No. I/Januari 2022 Al-Iqtishod | 67 


\section{Hasil dan Pembahasan}

\section{Biografi Ibn Taimiyah}

Ibn Taimiyah lahir di Harran pada 22 Januari tahun I26M atau IO Rabiulawal tahun 661H. beliau merupakan anak dari Abdul Halim dan merupakan keturuna dari Ulama besar yakni Mazhab Hambali pada usia 7 tahun Ibn Taimiyah telah menyelesaikan pendidikannya dalam bidang fiqh, hadist, tafsir al-Qur'an, filsafat dan juga matematika yang di gurui oleh Abd Majid, Ahmad bin Abu alkhair, yahya bin shairafi dan masih banyak lagi. Selain dari keluarga yang berpendidikan tinggi rupanya Ibn Taimiyah ini juga memiliki minat dan bakat dalam hal menulis, sehingga banyak sekali jumlah buku yang pernah ditulisnya. ${ }^{6}$ Adapun Buku-buku yang sudah beliau ciptakan antara lain, buku pertama yang dibuatnya berisi tentang pasar dan intervensi pemerintah mengenai ekonomi, yang kedua membahas tentang pendapatan sekaligus pembiayaan publik. ${ }^{7}$

Masa kelahiran Ibn Taimiyyah yaitu sekitar abad 7-8H merupakan masa yang bergejolak dengan politik sekaligus titik balik dalam sejarah dunia Islam. Pada masa itu Islam mengalami kemerosotan, kaum muslim bercerai berai karena terpecah belah kedalam berbagai negara-negara kecil. Dan para penguasa pimpinan seperti raja-raja menganggap raja yang lainnya adalah musuh mereka sehingga pada saat itu mereka saling membunuh satu sama lain. Di tahun 667H atau I26M keluarga ibn Taimiyyah berimigrasi ke Damaskus dengan membawa kitab-kitab yang berharga dengan menggunakan beberapa pedati untuk menghindari kekejaman kaum Mongol.

Ayah dari Ibn Taimiyyah terkenal sebagai penghafal sekaligus pengajar Hadist, penerjemah, ahli imu nahwu dan ilmu ushul, tidak heran Ibn Taimiyyah juga belajar menghafal Al-Qur'an, hadis, tafsir, mantik, filsafat, kalam, aljabar, kimia, ilmu falak,Selain itu didalam sejarah tercatat bahwa Ibn Taimiyyah ini pernah menggantikan kedudukan ayahnya yakni sebagai guru besar hadis dan fiqih Hambali dibeberapa sekolah terkenal di daerah Damaskus. Sejak dari peristiwa ini karir dari Ibn Taimiyyah ini terus menerus meningkat. Tidak hanya itu beliau juga terkenal sebagai juru pengubah yang tidak rela menyaksikan keadaan kaum muslim menjadi terbengkalai karena kurangnya pemahaman

${ }^{6}$ Rofiq, "Pemikiran Ekonomi Islam Ibnu Taimiyah."

7 Meriyati, "Pemikiran Tokoh Ekonomi Islam: Ibnu Taimiyah," Islamic Banking 1, no. 1 (2016):

24.

68| Al-Iqtishod Volume. I0/No. I/Januari 2022 
terhadap ilmu agama. Sehubungan dengan hal tersebut Ibn Taimiyyah berusaha melakukan pemurnian serta pembaharuan dalam islam.

\section{Prinsip Ekonomi Islam}

\section{a. Tauhid}

Dalam setiap perbuatan hal yang paling utama adalah memiliki prinsip tauhid, apalagi dalam sistem perekonomian islam. Sebab prinsip tauhid ini merupakan prinsip yang bersangkutan antara dunia dan akhirat. Seseorang yang menanamkan prinsip ini pada dirinya bisa terhindar dari hal-hal yang dilarang dalam agama ataupun pemerintah, meskipun dia melakukannya dalam keadaan yang sangat mendesak sekaligus tidak ada orang yang mengetahui perbuatan yang dilakukannya itu, sebab dia akan selalu merasa bahwa segala perbuatannya akan selalu diawasi oleh Allah SWT. Sehingga ketika dia akan melakukan kecurangan itu dia akan tidak akan berani untuk melakukan hal tersebut.

\section{b. Prinsip akidah}

Selain tauhid seseorang juga harus memiliki prinsip akidah, dimana akidah ini menjadi pondasi pertama yang akan menopang prinsip-prinsip yang lain. Sedangkan Kesadaran prinsip tauhid lah yang akan mengantarkan seseorang terhadap keyakinan dunai menuju akhirat, sehingga perbuatannya tidak akan hanya mengejar keuntungan dari ekonominya saja, melainkan juga mencari ridha Allah yang mana akan menyelamatkan dia kelak di akhirat dari siksaan yang amat pedih.

\section{c. Prinsip kebebasan}

Prinsip ini merupakan prinsip yang akan mengantarkan seorang muslim untuk yakin bahwa Allah SWT memiliki kebebasan secara mutlak dalam segala hal, sedangkan manusia hanyalah perantara yang diberi sebuah anugerah untuk dapat menjalankan sebuah usaha dan dapat memilih dan memilah antara yang hak dan yang batil. Setiap manusia tentunya diberikan anugerah serta kenikmatan kebebasan yang sama untuk melakukan sesuatu dan juga memanfaatkan kekayaannya dengan cara yang mereka inginkan.

\section{d. Prinsip keadilan}

Volume. I0/No. I/Januari 2022 A1-Iqtishod | 69 


\section{Pemikiran Ekonomi Ibn Taymiyah}

Menurut ajaran-ajaran yang terdapat didalam ekonomi islam, islam tidak pernah memaksa semua orang untuk bisa diletakkan pada tingkatan yang sama. Agar kebijakan yang diberikan dalam ekonomi islam dapat berjalan dengan baik,benar dan juga lancar, oleh karena itu dalam aturan-aturan yang talah ditetapkan, prinsip keadilan merupakan prinsip yang ada dalam proses distribusi serta institusi yang berperan dalam menciptakan suatu keadilan.

\section{e. Prinsip keseimbangan}

Dalam Perjanjian dengan berbagai macam aspek yang sudah banyak dikaji oleh para ahli di bidangnya, sehingga dapat melahirkan berbagai macam pengertian terkait dengan prinsip keseimbangan ini. Yang dalam bahasa Belanda "evenwicht-evenwichting", dalam bahasa Inggris " equality-equal-libirium "Yang jika diartikan ke dalam bahasa indonesia adalah keseimbangan-seimbangan yang memiliki makna sama atau rata yang biasanya dipergunakan dalam suatu keadaan, posisi, derajat, berat dan lain-lain. ${ }^{8}$

\section{f. Prinsip Tanggung jawab}

Dalam ajaran Islam seorang manusia berhak untuk memilih jalan hidup dan bebas dalam memilih sebuah usaha perekonomian yang diinginkannya. Namun, kebebasan tersebut harus dapat didasari dengan rasa tanggung jawab, sebab selain memiliki hak dia juga memiliki kewajiban yang harus di penuhi. Dan segala perbuatan yang dilakukan pastinya akan dimintai pertanggung jawaban baik di dunia ataupun di akhirat. Apalagi tentang ekonomi yang bersangkutan dengan khalayak, tentunya pertanggung jawabannya pasti lebih besar. Sehingga dalam hal ini kita perlu berhati-hati serta berbuat dengan seadil dan sebenar mungkin.

Pertanggung jawaban dibedakan menjadi dua aspek menurut konsep yang tercatat sejak awal perekonomian islam hadir yakni:

I. Tanggung jawab yang menyatu dengan status kekhalifahan manusia dimuka bumi sebagai wakil tuhan untuk menjaga seeta melestarikan bumi dengan sebaik-baiknya, karena manusia adalah makhluk ciptaan Tuhan yang paling sempurna diantara makhluk makhluk yang lain.

\footnotetext{
8 Jetta, "Pemikiran Hukum Islam Ibnu Taimiyah."
} 
2. Konsep tanggung jawab pada dasarnya menurut pandangan islam sifatnya adalah sukarela serta tidak terdapat campur tangan pemerintah untuk memaksa menerima atau menolak suutu perbuatan.

\section{Pokok pemikiran ekonomi islam Ibnu Taimiyah}

Untuk menghindari adanya monopoli yang dilakukan oleh pihak-pihak tertentu yang menindas pihak lainnya, sangatlah perlu bagi semua orang mengetahui tentang ilmu perekonomian terutama ekonomi islam, agar tidak ada manipulasi data tentang transaksi ekonomi yang merugikan orang lain. Sehingga jika semua orang sudah memahami tentang perekonomian diperkirakan akan menekan kasus penyelewengan.

Adapun tujuan terbesar dari pemikiran ekonomi Ibn Taimiyah adalah untuk melaksanakan kebaikan dan mencegah terjadinya perbuatan yang tidak diinginkan (munkar) melalui cara :

\section{a. Menghilang kemiskinan}

Seseorang yang hidupnya sejahtera yang hidupnya tidak tergantung kepada orang lain, memiliki kewajiban untuk bisa membantu yang lain terutama dalam hal keagamaan. Menghilangkan atau meminimalisir kemiskinan bisa dilakukan dengan cara memberikan bantuan kepada mereka yang sangat membutuhkan yaitu dengan memberikan sedekah atau zakat, lebih-lebih mereka yang memiliki harta yang sudah mencapai batasan-batasan diwajibkannya untuk membayar zakat maal, maka hendaklah dia melakukannya. Sebab hal ini akan berdampak positif baginya dan juga orang lain.

\section{b. Keuntungan yang adil}

Selain untuk menghilangkan kemiskinan baliau juga menganjurkan kepada umat manusia terutama orang muslim, dalam menjalankan kegiatan usaha seperti berjualan hendaklah dia mengambil keuntungan secara umum tanpa harus merusak kepentingan dari para pelanggannya, keuntungan yang adil yang dimaksudkan adalah mengambil keuntungan secara normal seperti keuntungan pada umumnya. Tujuan utama dari harga yang setara adalah memelihara keadilan dalam mengadakan transaksi timbal balik dan hubungan-hubungan lain diantara anggota masyarakat. Pada konsep 
Pemikiran Ekonomi Ibn Taymiyah

harga yang setara pihak penjual dan pembeli harus sama-sama merasakan keadilan. ${ }^{9}$

\section{c. Regulasi Harga}

Ibn Taimiyah membedakan dua tipe regulasi penetapan harga yaitu:

a. Tidak adil sekaligus tidak untuk memaksa seseorang untuk menjual barang dagangan tanpa ada dasar kewajiban untuk menjual ini.

b. Adil dan sah ketika pemerintah memerintahkan seseorang untuk berjualan dengan harga yang jujur, dan si penduduk tersebut membutuhkannya. ${ }^{10}$

Ketika ingin membuat regulasi harga,pertama harus membedakan terlebih dahulu antara pedagang lokal yang memiliki stok barang dengan para pedagang impor. ${ }^{11}$ Didalam sejarah Ekonomi islam, kebebasan ekonomi telah dijamin oleh berbagai macam tradisi yang ada dimasyarakat dan juga dengan sistem hukumnya. Rasulullah SAW juga pernah bersabda didalam salah satu hadis mengenai penetapan harga meskipun pada saat itu harga harga barang melampaui sangat tinggi. Diriwayatkan dari anas bin malik Ra: dari Anas bin MalikRA berkata :" Harga barang-barang pernah mahal pada masa Rasulullah SAW kemudian orang-orang berkata "ya. Rasulullah harga-harga menjadi mahal, tetapkanlah standar harga untuk kami", lalu Rasulullah SAW bersabda " Sesungguhnya Allah lah yang menetapkan harga, yang menahan serta membagi rezeki, dan sesungguhnya saya mengharapkan agar saya dapat berjumpa dengan Allah SWT dalam keadaan tidak seorangpun diantara kamu sekalian yang menuntut saya karena kedzoliman dalam pertumpahan darah dan harta". (HR. lima perawi kecuali An-Nasai). ${ }^{12}$ Hadis ini mengungkapkan bahwasanya Rasulullah SAW tidak ingin ikut campur dalam penetapan regukasi harga barang, akan tetapi naik turunnya harga disebabkan oleh kondisi objektif pasar bukan disebabkan adanya kecurangan.

Ibn Taimiyah juga menjelaskan bahwasanya naik turunnya harga tidak sertamerta sebabkan oleh tindakan sewenang-wenang dari seseorang akan tetapi bisa juga disebabkan karena penawaran harga yang menurun akibat adanya inefisiensi produksi,

\footnotetext{
9 Surya Darma Putra, "Pemikiran Ibnu Taimiyah Tentang Standar Harga Dalam Jual Beli," JES (Jurnal Ekonomi Syariah) 2, no. 1 (2011): 45.

10 fasiha, "Al-Amwal : Journal of Islamic Economic Law September 2017, Vol. 2, No. 2

Http://Www.Iainpalopo.Ac.Id/Index.Php/Amwal."

${ }^{11}$ Abu Yusuf and Ibnu Taymiyah, "MEKANISME PASAR DALAM PERSPEKTIF ISLAM" 8 , no. 1 (n.d.): 27.

12 Meriyati, "Pemikiran Tokoh Ekonomi Islam: Ibnu Taimiyah."
} 
penurunan jumlah barang yang diminta atau bisa juga karena tekanan pasar. ${ }^{13}$

\section{d. Mekanisme Pasar}

Mekanisme pasar merupakan proses penetapan harga barang berdasarkan kekuatan dari permintaan dan penawaran yang mana permintaan dan penawaran ini harganya harus seimbang. Proses keseimbangan mekanisme pasar berasal dari mana saja, baik dari permintaan atau penawaran. Adapun perubahan-perubahan tersebut bisa meliputi:

a. Perubahan bisa berasal dari permintaan

b. Perubahan bisa berasal dari penawaran

c. Perubahan bisa dari kedua sisi permintaan dan juga penawaran ${ }^{14}$

Ibn Taimiyah juga berargumentasi bahwa ada beberapa faktor yang dapat mempengaruhi terhadap permintaan dan juga penawaran sehingga berakibat terhadap harga pasar, diantaranya yaitu:

a. Keinginan yang berubah-ubah terhadap barang

b. Perubahan tersebut karena jumlah permintaan barang

c. Harga dipengaruhi oleh sistem pembayaran

d. Harga dipengaruhi oleh bentuk daripada pembayaran transaksi jual-beli

e. Meluasnya jumlah barang dan ukuran kebutuhan sangat minim atau besar juga bisa berpengaruh terhadap menguat atau melemahnya tingkat kebutuhan

f. Adanya tujuan kontrak jual-beli

g. Aplikasi yang digunakan seseorang dalam sewa-menyewa adalah sama.

Seperti halnya para pedagang yang menjual barang-barang dipasar tradisional, disana dalam mengambil keuntungan harus bisa menyesuaikan dengan keadaan di daerah tersebut dan para pedagang tidak boleh saling merugikan satu sama lain. Sebab pasar tradisional merupakan tempat bertemunya seorang penjual dan pembeli secara langsung untuk menjual membeli kebutuhan sehari-hari. Didalam konteks persaingan global dalam mempertahankan pasar tradisional dianggap sebagai salah satu tindakan yang tepat sebab roda perekonomian rakyat akan tetap berjalan serta memberikan peluang kepada para pedagang kecil agar tetap melanjutkan dan mengembangkan usaha mereka. Berbelanja dipasar tradisional cendrung lebih murah dibanding dengan

13 Rofiq, "Pemikiran Ekonomi Islam Ibnu Taimiyah."

14 ABD ADIM, "PANDANGAN IBNU TAIMIYYAH PERSPEKTIF EKONOMI ISLAM,"

Angewandte Chemie International Edition, 6(11), 951-952. 2, no. 2 (2021): 42.

Volume. IO/No. I/Januari 2022 A1-Iqtishod |73 


\section{Pemikiran Ekonomi Ibn Taymiyah}

berbelanja di toko modern seperti minimarket, swalayan dan masih banyak lagi pasar modern yang saat ini hadir.

\section{e. Kebijakan moneter}

Menurut ajaran agama islam kebijakan moneter merupakan kebijakan yang harus terbebas dari unsur riba, Dalam kebijakan moneter peran pemerintah dalam mencetak mata uang harus sesuai dengan transaksi yang adil dari masyarakat tanpa kedzoliman. Pemerintah harusnya mencetak uang dengan harga yang sebenarnya tidak boleh melebih-lebihkan, sebab tujuannya bukan untuk mencari keuntungan dari percetakan uang tersebut sehingga bisa menjamin kesejahteraan masyarakat.

\section{a. Karakteristik dan Fungsi Uang}

Uang memiliki dua fungsi utama menurut beliau yaitu: pertama, uang sebagai alat tukar, yang kedua yakni sebagai alat ukur dari benda yang ingin dibeli. Sebagaimana sabda beliau "Atsman (harga, yaitu sebagai pengukur nilai barangbarang (mi'yar al'amwal) yang jumlah nilai barang-barang (maqadir al amwal) bisa diketahui serta uang tidak pernah dimaksudkan untuk diri mereka sendiri.

\section{b. Penurunan harga mata uang}

Saran Ibn Taimiyyah terhadap pemerintah supaya tidak menggunakan bisnis mata uang dengan tembaga, mencetak menjadi mata uang kemudian hal ini digunakan untuk berbisnis, juga tidak membatalkan masa berlaku mata uang yang sedang beredar dikalangan masyarakat. Dan sekaligus menegaskan bahwasanya perdagangan uang akan membuka lebar pintu kedzaliman terhadap masyarakat dan juga bisa melenyapkan kekayaan dengan dalih yang tidak tepat. Dalam perspektifnya mengenai nilai mata uang seperti uang logam seharusnya bisa diciptakan sesuai dengan daya beli yang terjadi didalam pasar sehingga tidak seorangpun termasuk penguasa yang bisa mengambil keuntungan dengan melebur uang itu serta menjualnya ke dalam bentuk koin serta memasukkannya kedalam peredaran mata uang.

\section{f. Hak Milik}

Menurut pandangan agama islam yang berkaitan dengan hak kepemilikan segala sesuatu, pada hakikatnya hanyalah milik Allah SWT saja bukan milik yang lainnya, namun Ibn Taimiyyah mengemukakan argumentasinya bahwasanya tentang hak kepemilikan sesuatu sebenarnya bisa saja menjadi milik manusia akan tetapi dalam konteks ini dalam hal kepemilikannya tidak bertentangan dengan prisip-prinsip 
didalam syariah. Dalam hal kepemilikan yang terdapat didalam syariah telah dibentuk menjadi berbagai variasi tingkat hak kepemilikan.

Adapun Tingkatan-tingkatan tersebut adalah sebagai berikut :

\section{a. Hak milik Pribadi}

Dalam syariah ada beberapa hak yang di khususkan kepada seseorang dalam hal kepemilikan salah satunya adalah kepemilikan harta benda, sehingga agar bisa memiliki kekuatan yang khusus terhadap kepemilikan harta tersebut baik untuk diambil kemanfaatannnya atau mentasharufkan harta tersebut.

\section{b. Hak Milik Sosial}

Hak milik sosial merupakan hak untuk menggunakan atau mengambil manfaat dari suatu benda dengan hak yang sama seperti: air,rumput, api. Dalam salah satu hadist Rasulullah pernah bersabda " Manusia itu berserikat (dalam pemanfaatan tiga hal yaitu: air, rumput dan juga api” (HR. Ahmad bin Hambal). Adapun salah satu alasan adanya hak kepemilikan bersama yaitu: kepemilikan kolektif terhadap objek-objek alam karena semua itu Allah berikan kepada makhluknya secara gratis, untuk kepentingan bersama supaya mereka bisa untuk memenuhi kebutuhuan hidupnya dan juga untuk bisa lebih tekun lagi beribadah kepada Allah SWT.

\section{c. Hak Milik Negara}

Hak milik negara merupakan hak yang diberikan kepada pihak-pihak yang berwewenang untuk mengatur, mengelola serta memafaatkan sesuatu yang mana sesuatu ini hanya boleh digunakan untuk kepentingan yang bersangkutan dengan negara saja. Salah satunya yaitu pendapatan. Pendapatan negara biasanya di peroleh melalui sumber daya alam yang dikelola oleh sumber daya manusia untuk bisa menghasilkan sesuatu yang bermanfaat. Adapun menurut Ibn Taimiyah pada masanya dulu pendapatan negara yang paling besar diperoleh melalui zakat dan juga harta rampasan perang (ghanimah)

\section{g. Mencegah adanya kesenjanagan Sosial}

Dalam ekonomi islam lebih mengutamakan untuk bisa memberikan bantuan terhadap orang lain yang lebih membutuhkan dari pada untuk dibuat foya-foya atau hal-hal yang tidak ada manfaatnya. Meskipun ini juga merupakan hak masing-masing individu namun hal ini sangatlah di anjurkan oleh baginda Rasulullah SAW. Dan hal ini juga tertuang didalam firman Allah SWT dalam Al-Qur'an surah An-Nur ayat 56

Volume. IO/No. I/Januari 2022 Al-Iqtishod|75 


\section{Pemikiran Ekonomi Ibn Taymiyah}

yang berbunyi " Dan dirikanlah sholat, tunaikan zakat, dan taatlah kepada rasul, agar kamu diberikan rahmat”.

\section{Relevansi Pemikiran Ibn Taimiyah}

Agama islam merupakan agama yang paling sempurna diantara agama yang lain, karena didalam agama islam kita berpedoman terhadap kitab suci Al-Qur'an yang di wahyukan oleh Allah kepada Rasulullah yang dijadikan sebagai petunjuk kehidupan bagi seluruh umat terutama umat muslim, sebab didalam Al-Qur'an segala aspek kehidupan baik duni maupun di akhirat baik sebelum manusia lahir ataupun sudah meninggal semua dijelaskan secara detail termasuk kegiatan untuk memenuhi kebutuhan hidup seperti kegaiatan bermuamalah dan sebagainya. Dan dalam asumsi Ibn Taimiyah mengenai kegiatan perekonomian sangatlah penting dalam hati kita untuk menanamkan prinsipprinsip yang sesuai dengan kaidah islam serta menerapkannya dalam kehidupan sehari-hari seperti yang telah dierangkan didalam Al-Qir'an dan As-sunnah dan beliau juga berpedoman terhadap kedua sumber hukum islam tersebut, sehingga pemikirannya terhadap ekonomi juga sudah tidak diragukan lagi.

Prinsip-prinsip yang telah ditetapkan oleh agama islam terhadap ekonomi islam tentunya memiliki fungsi dan tujuannya masing-masing namun saling berkaitan seperti prinsip tauhid dan akidah keduanya sama-sama mengatur hubungan manusia dengan Allah sehingga dalam melakukan apapun orang tersebut akan selalu ingin melakukan hal yang terbaik. Prinsip kebebesan, keseimbangan, keadilan serta pertanggung jawaban, semua prinsip ini juga memeiliki tujuan dan fugsi yang berkaitan satu sama lain dan tidak dapat dipisahkan karena semua prinsip ini juga mengatur hubungan manusia dengan manusia dan juga hubugan manusia dengan Allah.

Dalam pemikiran Ibn Taimiyah mengenai tujuan utamanya yaitu untuk menyeimbangkan perekonomian dikalangan masyarakat sehingga terhindar dari monopoli ada hal-hal yang perlu di ingat dalam kegiatan ekonomi yaitu untuk meminimalisir adanya kemismkinan sehingga untuk bisa mewujudkan hal ini maka dalam ekonomi harga yang diberikan haruslah adil dan seimbang denghan penawaran dan permintaan barang di lapangan, adapun upaya untuk dapat memberikan harga yang adil dan seimbang yaitu dengan cara menggunakan penetapan regulasi harga melalui mekanisme pasar dan 
kebijakan moneter yang dilakukan oleh pemerintah sehingga bisa menghindari kesenjangan sosial dan memastikan adanya kejelasan hak milik barang. Sehingga gagasan yang dikemukakan Ibn Taimiyah yang berpedoman pada sumber hukum islam memang benar dan di terapkan oleh masyarakat muslim.

\section{E. Simpulan}

Menurut Ibn Taimiyah dalam ekonomi islam terdapat beberapa prinsip yang harus dipenui ketika ingin melakukan perokonomian khususnya dalam ekonomi islam. Adapun prinsip-prinsip tersebut diantaranya yaitu: prinsip ketauhidan, prinsip kaidah, kebebasan,prinsip keadilan, prinsip kesrimbangan, prinsip tanggung jawab. Dari semua keseluruhan prinsip ini haruslah terpenuhi semuanya sebab prinsip-prinsip ini memiliki keterkaitan antara satu dengan yang lainnya tanpa boleh terpisahkan.

Setiap gagasan yang dikemukakan pastinya memiliki makna serta tujuannya tesendiri, begitu pula dengan gagasan dari pemikiran Ibn Taimiyah ini yaitu: untuk menimalisir tingkat kemiskinan yang terjadi dikalangan masyarakat, menciptakan suatu keadialan dalam mengambil keuntungan sehingga tidak ada yang merasa di rugikan, dapat menentukan regulasai hara dan mekanisme pasar sehingga memudahkan seseorang untuk mengambil keputusan dengan kebijaksanaan, serta dapat membedakan antara hak milik pribadi, milik sosial dan juga milik negara.

\section{F. DAFTAR PUSTAKA}

\section{ADIM, ABD. "PANDANGAN IBNU TAIMIYYAH PERSPEKTIF EKONOMI ISLAM."} Angewandte Chemie International Edition, 6(11), 951-952. 2, no. 2 (2021): 2013-15.

Dedi, Syarial. "Ekonomi Dan Penguasa (Pemikiran Ibn Taimiyah Tentang Mekanisme Pasar)." $A L$ FALAH : Journal of Islamic Economics 3, no. 1 (2018): 73. https://doi.org/10.29240/jie.v3i1.442.

fasiha. "Al-Amwal : Journal of Islamic Economic Law September 2017, Vol. 2, No. 2 Http://Www.Iainpalopo.Ac.Id/Index.Php/Amwal.” Islamic Economic 2, no. 2 (2017): 11127.

Istiqomah, Lailatul, Pemikiran Ekonomi Islam, and Ekonomi Global. "Jurnal Al-Iqtishod Jurnal Al-Iqtishod" 1, no. 1 (2019): 1-19.

Jetta, Yasin. "Pemikiran Hukum Islam Ibnu Taimiyah.” Jurnal Ilmiah Al-Syir'ah 8, no. 2 (2010): 437-58. https://doi.org/10.30984/as.v8i2.19.

Volume. IO/No. I/Januari 2022 A1-Iqtishod|77 
Pemikiran Ekonomi Ibn Taymiyah

Meriyati. "Pemikiran Tokoh Ekonomi Islam: Ibnu Taimiyah." Islamic Banking 1, no. 1 (2016): 23-33.

Putra, Surya Darma. "Pemikiran Ibnu Taimiyah Tentang Standar Harga Dalam Jual Beli.” JES (Jurnal Ekonomi Syariah) 2, no. 1 (2011): 120-36.

Rofiq, M Khoirur. "Pemikiran Ekonomi Islam Ibnu Taimiyah." An-Nawa, Jurnal Hukum Islam 22, no. 1 (2018): 28-60.

Yusuf, Abu, and Ibnu Taymiyah. "MEKANISME PASAR DALAM PERSPEKTIF ISLAM" 8, no. 1 (n.d.): $19-40$. 